\title{
Profitability, Earnings Per Share on Stock Return with Size as Moderation
}

\author{
Jumawan Jasman \\ jumawan@stiem.ac.id \\ Muhammad Kasran \\ STIE Muhammadiyah Palopo
}

\begin{abstract}
The purpose of this study was to analyze the effect of profitability and earnings per share on stock returns and the role of size as a moderating variable in state-owned companies listed in the Indonesia Stock Exchange (IDX) in the period of 2011-2016. By using purposive sampling, the number of samples included 18 companies. Method was conducted by downloading summary of financial statements in the Indonesia Stock Exchange. The research began with classical assumption test, multiple linear regression analysis was done with the absolute difference test. The research found that profitability had no effect on stock return. Earnings per share and size had a significant negative effect on stock return. The role of size as a moderating variable strengthened the relationship of earnings per share with stock returns, but it did not play a role in the relationship of profitability with stock returns.
\end{abstract}

Keywords: profitability, earnings per share, size, stock return

\section{INTRODUCTION}

The capital market in Indonesia as a container can awaken spirit, create or use it to build a more equitable and better economy that provides direct benefits to society. Therefore, its presence is very important for companies and investors. Companies that need funds can sell stocks and bonds to fund the activities of the company, while investors who have excess funds can invest in the capital market to get a return. Returns to shareholders other than dividends can also be capital gains, while returns for bondholders are in the form of interest.

Investors are very fond of the high income from each investment. But before they invest their funds, they need to do an analysis of the condition of the company to predict the future stock price in order for their expectations to be achieved. There are several sources of information that can be used to predict future stock prices such as the financial statements and economic conditions of a country. On the other hand, investors also need to consider the risks both systematic and nonsystematic. In addition, the difference in information between managers and investors can lead to losses for investors.

Some information from the financial statements can be a source to know the condition of a company such as profit. Companies that earn high profits are considered good for investors, that managers are able to manage their assets well. Profitability can be used to finance the company's operations and as a source of internal funds in the framework of corporate sustainability. It can also be used to improve shareholder wealth through dividend distribution. Companies that earn profits provide good news for potential investors. This will sign that the company is able to provide return to investors. So that potential investors will be interested to buy shares of the company. In the end, it will also increase the stock return.

Earnings per share is a ratio that shows net income for each share for shareholders. A higher ratio will be well valued by investors. Therefore, the tendency of potential investors to invest in shares of companies with high earnings per share will also increase. In the end, it will increase return for shareholders. Vice versa, if the ratio of earnings per share is low then potential investors will view the information content.

Companies that have large total assets will be easier to obtain loans than small companies. It has the resources to be used as collateral. On the other hand, large-scale companies have relatively greater growth compared to smaller companies. Therefore, the rate of return of a large company stock is higher than that of a small company. Therefore, investors will invest 
in large-scale companies in the hope of getting a great return as well.

Research conducted by Kheradyar et al (2011) find that financial ratios can be used to predict stock returns on the Malaysia Stock Exchange in the period of January 2000 to December 2009. While Suteja and Seran (2015) show that ROE, DER, NPM, inflation, exchange rate and interest rate provide a positive influence on stock returns of the automotive industry and components listed on the IDX in the period of 2009-2013. Masum (2014) finds that return on equity has a significant effect on stock price, while profit after tax and dividend yield have negative and significant effect on stock price at commercial bank which list in Dhaka Stock Exchange Bangladesh in the period of 2007-2011.

Research conducted by Farkhan and Ika (2013), Angraini (2014) and Safitri, et al. (2015) prove that profitability proxyed with return on asset have positive and significant effect on stock return. However, the findings of Bukit and Anggono (2013) show that return on assets has a negative and significant effect on stock returns. While the findings of Marlina and Sari (2009), Susilowati and Turyanto (2011), Arista and Astohar (2012) and Budialim (2013) show that profitability proxyed return on assets (ROA) has no effect on stock return. Azzam's finding (2010) shows that return on assets can reduce stock volatility.

Research conducted by Solechan (2009), Hermawan (2012), Bukit and Anggono (2013), \& Purwaningrat and Suaryana (2015) found that earnings per share has a positive and significant effect on stock return. Khan et al. (2013) found that earnings per share had a positive effect on stock returns on the Pakistani textile company in 2003-2009. Similarly, the findings of Ali et al. (2015) showed that earnings per share as a positive and significant effect on stock prices on non-financial companies in the KSE-100 index. In contrast to the findings of Susilowati and Turyanto (2011), Arista and Astohar (2012), Budialim (2013), and Zulaikha (2013) find that earnings per share had no significant effect on stock returns.

Research conducted by Sugiarto (2011), and Purwaningrat and Suaryana (2015) proved that size has a positive and significant effect on stock returns. In contrast, the findings Solechan (2009) and Anggriani (2014) found that size did not affect stock returns.

Motivation of this research is based on the curiosity of researchers to determine the effect of profitability and earnings per share on stock returns and how the role of company size in the relationship is. Interest to examine the stock returns on state-owned enterprises is based on the phenomenon of return that occurs and investor interest to invest in companies whose majority ownership of shares owned by the government. In addition, there is still a research gap on the relationship. The fundamental difference of this study with other studies is the size used as a moderating variable and using multiple linear regression analysis method with the value of absolute difference to see the effect of moderating variable.

According to the opinion of Jogiyanto (2010), information published as an announcement will provide a signal for investors in making investment decisions. If the announcement contains good news, the market reaction at the time of the announcement is accepted by the market. One of the information released by the company to potential investors is the annual financial statements. The information contained in the annual financial statements can be in the form of information about the condition of the company in the present. In addition to the fundamental information sourced from the company's financial statements, the information also comes from outside the company in the form of a country's economic conditions.

When information is announced and all market participants have obtained the information, market participants first interpret and analyze the information whether it's a good signal or a bad signal. If the announcement is considered good for investors, there will be increase in price and stock trading volume. But if the information is considered bad, it will reduce the price and volume of stock trading.

However, asymmetric information may occur when managers know more about internal information and future prospects of the company than shareholders and other stakeholders. The higher information asymmetry can lead to serious implications for company performance and sustainability. These two problems can drive managers to behave lazily and unethically. They can trick owners and other stakeholders into reporting information about the company's economic performance and resources.

According to the opinion of Joyianto (2010), return is the result of investment. Return can be realized return and expected return. Realized return is a return that has occurred, whereas expected return is a return that is expected and will be obtained by investors in the future. According to the opinion of Tandelilin (2010), return is an advantage gained from investment. The difference between the expected return and the received return is the risk that should always be considered in the investment process. Stock return is the main objective of every investor in investing. Stock return can be obtained by investors such as capital gains and dividends. Stock return on research only in terms of capital gains, where the capital gain is the difference between the purchase price and the selling price of stock.

According to the opinion of Ang (1997), return on assets is one of the profitability ratios used to measure the ability of companies in generating profits by utilizing assets owned. According to the opinion of Prastowo and Juliaty (2008), return on assets measures the ability of companies to utilize their assets to earn profits. Companies always strive to improve return on assets. 
This is because the higher return on assets shows the more effective the company utilizes the assets owned to obtain net profit after tax. With the increasing of return on assets, the profitability of the company becomes the better also.

Earnings per share is one of the market ratios that measure management's ability to create market value that goes beyond investment spending (Ang, 1997). This ratio is the most complete measurement to assess the company's achievements related to the company's goal of maximizing corporate value and shareholder wealth .

Company size is a description of the size of the company related to company's ability and opportunity to earn a profit. Large companies are considered to have larger resources and will generate higher profits than smaller companies. Therefore, the classification of this company can affect the value of the company.

\section{METHODS}

Population used in this research was all state-owned companies listed in Indonesia Stock Exchange (IDX) in the period of 2011-2016. Data was collected by purposive sampling technique which consisted of 1) State owned company listed in IDX during the period of 2011-2016,2) the company presented by the summary of financial statements in IDX in the period of 2011$2016,3)$ the company had required data for research including profitability, earnings per share, size and stock return. Based on these criteria, the number of companies that met the criteria as a sample was 18 companies for 6 years of observation.

The type of data in this study was secondary data obtained from Indonesia Stock Exchange (IDX) in the period of 2011-2016. Secondary data studied was panel data that is a combination of time series and cross section. The research variables included independent variables consisting of profitability proxyed with return on asset (X1), earnings per share (X2). Dependent variable was stock return (Y), while size (Z) as moderating variable. In order to avoid multiple interpretation, it would be described in detail such as stock return was percentage of current year closing stock price divided by last year's closing stock price (Tandelilin, 2010), return on asset was percentage of net profit divided by total asset of the current year (Ang, 1997), earnings per share was the percentage of net income divided by the number of shares outstanding in the current year (Ang, 1997), and size was the total asset logarithm of the current year.

This study began with classical assumption test so as not to deviate from the BLUE assumption (best, liniear, unbiased, and estimator). The classical assumption test used was normality test, multicollinearity test, and autocorrelation test. After that, hypothesis test with significance level of $5 \%$. To test the hypothesis used multiple liniear regression analysis with absolute difference test by means of independent variables minus moderating variables. The model in this research is:

$$
\begin{aligned}
\mathbf{R S}= & \boldsymbol{\alpha}+\boldsymbol{\beta}_{1} \mathrm{PROF}+\boldsymbol{\beta}_{2} \mathrm{EPS}+\boldsymbol{\beta}_{3} \mathrm{Size}+\boldsymbol{\beta}_{4} \mathrm{Abs}\left|\mathrm{X}_{1}-\mathrm{Z}\right| \\
& +\boldsymbol{\beta}_{5} \mathrm{Abs}\left|\mathrm{X}_{2}-\mathrm{Z}\right|+\varepsilon
\end{aligned}
$$

\begin{tabular}{|c|c|}
\hline 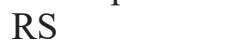 & stock return \\
\hline PROF & : profitability \\
\hline PS & ngs per share \\
\hline $\mathrm{ze}$ & company size \\
\hline- & $\begin{array}{l}\text { : absolute difference in profitability } \\
\text { with size }\end{array}$ \\
\hline - & $\begin{array}{l}\text { : absolute difference in earnings per } \\
\text { share with size }\end{array}$ \\
\hline${ }_{2}, \beta_{3}, \beta_{4}, \beta_{5}$ & $\begin{array}{l}\text { constant } \\
\text { regression coefficient } \\
\text { error term }\end{array}$ \\
\hline
\end{tabular}

Description:

\section{RESULTS}

To know whether the residual distributed normally or not, it is further using non-parametric statistical test, Kolmogorov-Smirnov test (K-S). The residual value is normally distributed if the significant value is greater than 5\% (Ghozali, 2014). The results of the normality test using one-sample Kolmogorov-Smirnov test show that the significant value (Asymp.Sig. (2-tailed)) is 0.832 which means greater 0.05 . It can be concluded that the residual values is normally distributed (Table 1).

Table 1. Normality Test Result One-Sample Kolmogorov-Smirnov Test

\begin{tabular}{llr}
\hline & & $\begin{array}{c}\text { Unstandardized } \\
\text { Residual }\end{array}$ \\
\hline $\mathrm{N}$ & Mean & 107 \\
Normal Parameters $^{\mathrm{a}, \mathrm{b}}$ & .0000000 \\
& Std. Deviation & 1.71435893 \\
Most Extreme & Absolute & .060 \\
Differences & Positive & .057 \\
& Negative & -.060 \\
Kolmogorov-Smirnov Z & & .624 \\
Asymp. Sig. (2-tailed) & & .832 \\
\hline
\end{tabular}

a. Test distribution is Normal.

b. Calculated from data.

Multi-colinearity can be seen on tolerance or variance inflation factor (VIF) with the provision of tolerance value $>10 \%$ and VIF value $<10$ then there is no multicollinearity. The multicollinearity test results in Table 2 shows that the value of variance inflation factor (VIF) is smaller than the critical limit value of 10 . In addition, the tolerance value is not below $10 \%$. Therefore, it can be concluded that there is no high correlation deviation of independent variables or multicollinearity. 
Table 2. Multicolinearity Test Result

\begin{tabular}{llcc}
\hline \multirow{2}{*}{ Model } & \multicolumn{2}{c}{ Collinearity Statistics } \\
\cline { 3 - 4 } & & Tolerance & VIF \\
\hline 1 & (Constant) & & \\
& Zscore: Profitability & .790 & 1.266 \\
& Zscore: Earnings per Share & .286 & 3.501 \\
& Zscore: Size & .897 & 1.115 \\
& AbsX1_Z & .624 & 1.604 \\
& AbsX2_Z & .241 & 4.156 \\
\hline
\end{tabular}

Autocorrelation was detected using the DurbinWatson test (DW Test). The Durbin-Watson value between the du and 4-du value indicate a model with no autocorrelation problem (Ghozali, 2014). Based on Table 3, the Durbin-Watson value is 2.142 . The value of table du for $\mathrm{k}=3$ and 107 data is obtained at 1.736 . Thus, $4-\mathrm{du}=4-1,736=2,264$. So that's $1,736<2,142<2,264$. This means no positive and negative autocorrelation.

Table 3. Autocorrelation Test Result Model Summary ${ }^{\mathrm{b}}$

\begin{tabular}{cccccc}
\hline Model & $\mathrm{R}$ & $\begin{array}{c}\mathrm{R} \\
\text { Square }\end{array}$ & $\begin{array}{c}\text { Adjusted } \\
\text { R Square }\end{array}$ & $\begin{array}{c}\text { Std. Error of } \\
\text { the Estimate }\end{array}$ & $\begin{array}{c}\text { Durbin- } \\
\text { Watson }\end{array}$ \\
\hline 1 & $.279^{\mathrm{a}}$ & .078 & .051 & 215.37735 & 2.142 \\
\hline a. Predictors: (Constant), Zscore $(\mathrm{Z})$, Zscore $\left(\mathrm{X}_{1}\right)$, Zscore $\left(\mathrm{X}_{2}\right)$ \\
b. Dependent Variable: Stock Return
\end{tabular}

In Table 4 the coefficient of determination shown by Adj. R2 of 0.089 (8.9\%). This indicates that Zscore profitability, Zscore earnings per share, Zscore size, AbsX1-Z and AbsX2 - Z in explaining stock return is $8.9 \%$. The remaining $91.1 \%$ is explained by other variables outside the model. With low Adj R2 value, the model built in this research has not been good. In other word, there are still variables outside the model that is very influential on stock returns.

Based on Table 4, it shows the F-Statistic value of 3,069 with a significant value of 0.013 smaller than 0.05 . This means that all independent variables simultaneously affect the stock return. The beta coefficient value of profitability is -0.571 with a significance value of 0.569 greater than 0.05 . Negative coefficient value can be interpreted with the increase profitability of $1 \%$, stock return that will decrease to $57,1 \%$ and vice versa. With a significance value greater than 0.05 then profitability has no significant effect on stock return.

The value of beta coefficient of earnings per share is -1.989 with a significance value of 0.049 smaller than 0.05 . The value of negative and significant coefficients can be interpreted that the increase of $1 \%$ earnings per share of the company, the stock return will fall by $198.9 \%$. Therefore, the earnings per share has a significant negative effect on stock return.
The beta coefficient value of size is -2.818 with a significance level of 0.006 smaller than 0.05 . Negative and significant coefficient value can be interpreted that the increase of $1 \%$ company size, the stock return will decrease by $281.8 \%$ and vice versa, if other variables are considered constant. Therefore, it can be concluded that size has a significant negative effect on stock return.

Tabel 4. Multiple Regression Result Summary by using Absolute Difference Test

\begin{tabular}{|c|c|c|c|}
\hline & $\begin{array}{l}\text { Standardized } \\
\text { Coefficients }\end{array}$ & $\mathrm{T}$ & Sig \\
\hline (Constant) & & -.228 & .820 \\
\hline Zscore: Profitability & -.060 & -.571 & .569 \\
\hline Zscore: Earnings Per Share & -.345 & -1.989 & .049 \\
\hline Zscore: Size & -.276 & -2.818 & .006 \\
\hline $\operatorname{AbsX}_{1 \_} Z$ & -.107 & -.908 & .366 \\
\hline $\mathrm{AbsX}_{2} \mathrm{Z}$ & .468 & 2.474 & .015 \\
\hline $\mathrm{N}=107$ & & & \\
\hline $\mathrm{R}^{2}=.132$ & & & \\
\hline Adj $R^{2}=.089$ & & & \\
\hline F-Statistic $=3.069$ & & & \\
\hline Sig. $=0.013^{\mathrm{b}}$ & & & \\
\hline
\end{tabular}

The beta coefficient value of AbsX1-Z is -0.107 with a significance level of 0.366 greater than 0.05 . This shows that if the value of absolute difference between profitability and firm size increases by $1 \%$ then stock return will decrease by $10.7 \%$. A significance value greater than 0.05 indicates that size does not act as a moderating variable on profitability relation with stock return.

The beta coefficient value of AbsX2-Z is 0.468 with a significance level of 0.015 smaller than 0.05 . This shows that if the value of absolute difference between earnings per share and firm size increases by $1 \%$ then stock return will also increase by $46.8 \%$. Therefore, it can be concluded that size can be a moderating variable on the relationship of earnings per share with stock returns.

\section{DISCUSSION}

Based on the test results, it indicated that profitability had no significant effect on stock return of state-owned companies listed in Indonesia Stock Exchange (IDX) period 2011-2016. Thus, the increase in profitability did not increase the stock return of companies that could prosper the investors. The result of this research is caused by asymmetry information between investor and manager. Investors do not make profitable profits from the use of corporate assets as a fundamental factor that can influence stock prices to rise, but there are other 
elements such as government-majority ownership that contains a lot of pressure and regulation.

These finding was in line with research conducted by Sunardi (2010), Susilowati and Turyanto (2011), Arista and Astohar (2012) who found that profitability had no effect on stock returns. Similarly, the findings of Har and Ghafar (2015) found that during pre-recession economy, return on assets affected stock return but at the time of recession return on assets had no effect on stock return. In contrast to Allozi and Obeidat (2016), this study found that GPM, ROA, ROE had a significant effect on stock return on manufacturing companies registered in Amman Stock Exchange. Khan et al. (2013) found that the return on equity ratio had a positive effect on stock return on textile companies in Pakistan for the period 2003-2009.

Test results showed that earnings per share had a negative and significant effect on stock return of stateowned companies listed in Indonesia Stock Exchange (IDX) in the period of 2011-2016. This meant that companies that experience an increase in earnings per share, the stock return would fall. In contrast to the theory that investors capture information with an increase in earnings per share will increase the company's stock price, also impact on increasing stock return of the company. This occurs because of certain characteristics in state-owned companies and preferences of investors other than the government.

This result was different from Uddin et.al. (2013) who found that earnings per share had a strong relationship with stock price in the financial sector in Bangladesh. Hermawan (2012), Bukit and Anggono (2013), Purwaningrat and Suaryana (2015) found earnings per share had a positive and significant effect on stock return. Allozi and Obeidat (2016) found that EPS had a significant effect on stock return on manufacturing companies listed in the Amman Stock Exchange in the period of 2001-2011. Khan et al. (2013) found that earnings per share had a positive effect on stock returns on the Pakistani textile company in 2003-2009. Masum (2014) found that return on equity and earnings per share had a positive and significant effect on stock price, while profit after tax and dividend yield had negative and significant effect on stock price at commercial bank which list in Dhaka Stock Exchange Bangladesh in the period of 2007-2011.

The test results showed that size had a negative and significant effect on stock return of state-owned companies listed in Indonesia Stock Exchange (IDX) in the period of 2011-2016. This means that the larger the size of the company then stock return will fall. These results indicated the company size that was proxyed by total assets

This is different from the theory that the higher the size of the company the higher the stock return of the company. This finding was different from the findings by Sugiarto (2011), Purwaningrat and Suaryana
(2015) that found that company size had a positive effect on stock returns on companies listed in Indonesia Stock Exchange in the period of 2011-2013. Research conducted by Sugiarto (2011), and Purwaningrat and Suaryana (2015) proved that size had a positive and significant effect on stock returns. In contrast to findings by Solechan (2009) and Anggriani (2014) who found that size did not affect stock return.

Based on the results of testing of moderating variables using multiple regression analysis model with absolute difference value, it indicated that size could not act as moderating variable on profitability relation with stock return on state-owned company listed in Indonesia Stock Exchange (IDX) period 2011-2016. The existence of size variable could not strengthen or weaken the relationship between profitability with stock returns indicating that firm size was not a moderating variable of the relationship between profitability and stock return. Thus, large and low size companies did not increase or decrease the impact of profitability on stock return.

Based on the results of testing of moderating variables using multiple regression analysis model with absolute difference value, it showed that the size acted as a moderating variable on the relationship of earnings per share with stock return. The value of positive coefficient can be interpreted that size strengthens the effect of earnings per share on stock return on state owned companies listed in Indonesia Stock Exchange period 2011-2016. This finding showed that the higher earnings per share of a company will increase the stock return and will increase if the size of the company is also large. This finding was in line with Sugiarto (2011), and Purwaningrat and Suaryana (2015) that proved that size had a positive and significant effect on stock returns.

\section{CONCLUSION}

Research findings on state-owned companies listed on the IDX in the period of 2011-2016 that are profitability did not significantly affect the stock return. The ability to earn both high and low earnings has not been able to affect stock return. Earnings per share had a negative and significant effect on stock return. Companies that have high earnings per share will result in low stock returns. Size had a negative and significant effect on stock return. Companies that have firm size in this case high total assets will result in low stock returns. Company size could not be used as a moderating variable between profitability and stock return. Company size strengthen the relationship between earnings per share and stock return. Therefore, companies with good earnings per share will increase stock return on companies with large assets.

The results of this study contribute to profitability does not affect the stock return. Therefore, it can be 
used as reference for further research in the field of financial management. Earnings per share gives a negative signal to stock returns. Size can be used as independent variable and also moderating variable. In addition, managers of state-owned companies need to be more efficient and effective in using their assets to generate profits to attract investors to invest according to signaling theory.

\section{REFERENCES}

Allozi, N. M., \& Obeidat, G. S. (2016). The Relationship between the Stock Return and Financial Indicators (Profitability, Leverage): An Empirical Study on Manufacturing Companies Listed in Amman Stock Exchange. Journal of Social Sciences (COES\&RJJSS), Vol. 5(3): 408-424.

Ali et al. 2015. Effect of Dividend Policy on Stock Prices. Business \& Management Studies: An International Journal, Vol 3(1):56-87

Ang, R. 1997. Buku Pintar Pasar Modal Indonesia. Indonesia: Mediasoft

Anggraini, D. 2014. Corporate Social Responsibility (CSR) Sebagai Salah Satu Faktor yang Berpengaruh Terhadap Return Saham. Jurnal Akuntansi. Vol. 18(1): 71-85

Arista, D. dan Astohar. 2012. Analisis Faktor-Faktor yang Mempengaruhi Return Saham (Kasus pada Perusahaan Manufaktur yang Go Public di BEI periode tahun 2005-2009). Jurnal Ilmu Manajemen Dan Akuntansi Terapan. Vol. 3(1): 1-15

Azzam, I. 2010. The Impact of Intitutional Ownership and Dividend Policy on Stock Returns and Volatility : Evidence from Egypt. International Journal of Business, Vol. 15(4) : 443-458

Budialim, G. 2013. Pengaruh Kinerja Keuangan dan Risiko Terhadap Return Saham Perusahaan Sektor Consumer Goods di Bursa Efek Indonesia Periode 2007-2011. Jurnal Ilmiah Mahasiswa Universitas Surabaya. Vol 2(1): 1-23

Bukit, I.N.H. dan Anggono, A.H. 2013. The Effect of Price to Book Value (PBV), Dividend Payout Ratio (DPR), Return on Equity (ROE), Return on Asset (ROA), and Earning Per Share (EPS) Toward Stock Return on LQ 45 for Period of 2006-2011. Review of Integrative Business \& Economics Research. Vol. 2(2): 22-43

Farkhan dan Ika. 2013. Pengaruh Rasio Keuangan Terhadap Return Saham Perusahaan Manufaktur di Bursa Efek Indonesia (Studi kasus pada Perusahaan Manufaktur Sektor Food and Beverage). Jurnal Value Added. Vol.1: 1-18

Ghozali, I. 2014. Ekonometrika (Teori, Konsep, Aplikasi dengan IBM SPSS 22. Undip: Semarang
Har, W.P dan Ghafar, M.A.A. 2015. The Impact of Accounting Earnings on Stock Returns : The Case of Malaysia's Plantation Industry. International Journal of Business and Management, Vol 10(4): 155-166

Hermawan, D.A. 2012. Pengaruh Debt to Equity Ratio, Earning Per Share dan Net Profit Margin Terhadap Return Saham. Management Analysis Journal. Vol 1(5): 1-7

Jogiyanto, H.M. 2010. Teori Portofolio dan Analisis Investasi. Edisi Ketujuh, BPFE UGM, Yogyakarta

Khan et al. 2013. The Impact of Capital Structure and Financial Performance on Stock Returns "A Case of Pakistan Textile Industry". Middle-East Journal of Scientific Research, Vol 16(2): 289-295

Kheradyar, S., Ibrahim, I., dan Nor, F. M. (2011). Stock Return Predictability with Financial Ratios. International Journal of Trade, Economics and Finance, Vol 2(5): 391-396

Marlina Dewi dan Sari, Eka Nurmala Sari. 2009. Pengaruh Rasio Profitabilitas dan Leverage Terhadap Return Saham (Studi Empiris Perusahaan Manufaktur di BEI). Jurnal Riset Akuntansi dan Bisnis. Vol 9(1): 80-105

Masum, Abdullah A1. 2014. Dividend Policy and Its Impact on Stock Price-A Study on Commercial Banks Listed in Dhaka Stock Exchange. Global Disclosure of Economics and Business, Vol 3(1):9-17

Prastowo, D. dan Juliaty, R. 2008. Analisis Laporan Keuangan Konsep dan Aplikasi. Edisi 2, UPP AMP YKPN, Yogyakarta

Purwaningrat, P.A. dan Suaryana, I.G.N.A. 2015. Pengaruh Perubahan Earning per Share, Debt to Equity Ratio, dan Ukuran Perusahaan Pada Return Saham. E-Jurnal Akuntansi Universitas Udayana. Vol 10(2): 444-455

Safitri, et al. 2015. Analisis Pengaruh Profitabilitas, Likuiditas, dan Leverage Terhadap Return Saham Pada Perusahaan Manufaktur yang Terdaftar di BEI Tahun 2009-2013. Jurnal Akuntansi S1. Vol 3(1): $1-10$

Solechan, A. 2009. Pengaruh Earning, Manajemen Laba, IOS, Beta, Size dan Rasio Hutang Terhadap Return Saham Pada Perusahaan yang Go Public di BEI. Jurnal Akuntansi dan Auditing. Vol 6(1): 1-18

Sugiarto, A. 2011. Analisa Pengaruh Beta, Size Perusahaan, DER dan PBV Ratio Terhadap Return Saham. Jurnal Dinamika Akuntansi. Vol. 3(1): 8-14

Sunardi, H. 2010. Pengaruh Penilaian Kinerja dengan ROI dan EVA terhadap Return Saham pada Perusahaan yang Tergabung dalam Indeks $L Q$ 45 di Bursa Efek Indonesia. Jurnal Akuntansi. Vol.2(1): 70-92

Susilowati, Y dan Turyanto, T. 2011. Reaksi Signal Rasio Profitabilitas dan Rasio Solvabilitas Terhadap 
Return Saham Perusahaan. Jurnal Dinamika Keuangan dan Perbankan. Vol 3(1): 17-37

Suteja, J dan Seran, P. 2015. Determinan Return Saham Industri Otomotif dan Komponen yang Terdaftar di BEI. Trikonomika, Vol. 14(1): 76-86

Tandelilin, E. 2010. Portofolio dan Investasi Teori dan Aplikasi. Edisi Pertama. Indonesia: Kanisius

Uddin et al. 2013. Determinants of Stock Prices in Financial Sector Companies in Bangladesh- A Study on Dhaka Stock Exchange (DSE). Interdiciplinary Journal of Contemporary Research in Business. Vol 5(3): 471-480

Zulaikha, M.H.N. 2013. Pengaruh Earning Per Share, Return Saham, Kualitas Audit dan Hasil Laba Terhadap Return Saham Satu Tahun Kedepan (Studi Empiris pada Perusahaan Manufaktur yang terdaftar di BEI tahun 2010-2011). Jurnal of Accounting. Vol. 2(3): 1-9 